\title{
ЗАСТОСУВАННЯ ЕНТЕРОСОРБЕНТУ АУТ ДЛЯ КОРЕКЦІї ОКИСНЮВАЛЬНИХ ПРОЦЕСІВ ЗА ЕКСПЕРИМЕНТАЛЬНОГО КОЛОРЕКТАЛЬНОГО КАНЦЕРОГЕНЕЗУ В ЩУРІВ
}

\author{
๑О. І. Качур, Л. С. Фіра, П. Г. Лихацький \\ Тернопільський національний медичний університет імені І. Я. Горбачевського
}

РЕзюМЕ. Злоякісні новоутворення товстої кишки є одним з найпоширеніших захворювань шлунко-кишкового тракту. Для лікування цих захворювань, окрім протипухлинної терапії, застосовують терапію супроводу, зокрема, ентеросорбцію, яка призначена для виведення токсичних речовин із організму.

Мета - оцінити ефективність використання ентеросорбенту АУТ та його вплив на показники оксидативного стресу в організмі щурів за умов експериментального канцерогенезу.

Матеріал і методи. Експерименти виконано на білих щурах-самцях, яким моделювали рак товстої кишки шляхом щотижневого підшкірного введення 1,2-диметилгідразину в дозі 7,2 мг/кг маси тіла впродовж 30 тижнів. Ентеросорбент АУТ вводили інтрагастрально щоденно впродовж 21 доби після моделювання пухлини в дозі 1 мл на 100 г маси тіла тварини. Розвиток оксидативного стресу вивчали за активністю окисної модифікації протеїнів, концентрацією продуктів пероксидного окиснення ліпідів, супероксиддисмутазною та каталазною активністю.

Результати. Встановлено, що після ураження 1,2-диметилгідразин гідрохлоридом розвивається оксидативний стрес, який підтверджується підвищенням у сироватці крові та печінці щурів вмісту ТБК-активних продуктів та 2,4-динітрофенілгідразонів. В експериментальних тварин порушується проксидантно-антиоксидантний баланс, на що вказує зниження активності показників ензиматичної ланки антиоксидантної системи. Застосування ентеросорбенту АУТ сприяло нормалізації окиснювальних процесів та відновленню активності ензиматичної ланки антиоксидантної системи в умовах індукованого канцерогенезу.

Висновок. Отримані результати підтверджують позитивну динаміку використання детоксикаційної терапії сорбентом АУТ під час прогресуючого розвитку оксидативного стресу за умов змодельованого канцерогенезу.

КЛючОВІ СЛОВА: оксидативний стрес; антиоксидантна система; диметилгідразин; ентеросорбент АУТ; окисна модифікація протеїнів.

Вступ. Проблема злоякісних новоутворень шлунково-кишкового тракту залишається актуальною та потребує детального вивчення. Експериментальні моделі колоректального канцерогенезу у щурів відзначаються біохімічною та гістологічною подібністю до карциноми людини та дають можливість вивчити певні аспекти онкологічного процесу, які неможливо ефективно дослідити у людей. Штучно індукований канцерогенез товстої кишки моделюють шляхом введення хімічної речовини 1,2-диметилгідразину (ДМГ). Метаболізм канцерогену ДМГ відбувається в печінці, а його інтермедіати через жовч транспортуються до кишечника. Метаболічно активний ДМГ зумовлює модифікацію ДНК, гістонів, ДНК-зв'язуючих протеїнів клітин-мішеней $[12,14]$.

Внаслідок дії канцерогену ДМГ порушується внутрішньоклітинний гомеостаз, що сприяє розвитку оксидативного стресу. У результаті в організмі відбувається зміна інтенсивності пероксидного окиснення ліпідів (ПОЛ), накопичення в крові продуктів вільнорадикального окиснення та активних форм оксигену (АФО) $[15,17,19]$.

Для зменшення проявів оксидативного стресу використовують ентеросорбенти. Вуглецевий ентеросорбент АУТ має питому поверхню пор близько 2000-2500 м²/г, за рахунок чого проявляє сорбційні та детоксикаційні властивості. На осно- ві даного вуглецевого волокна запропоновано i досліджено вуглеволокнистий ентеросорбент четвертого покоління карболайн (АУТ) [8].

Мета - оцінити ефективність використання ентеросорбенту АУТ та його вплив на показники оксидативного стресу в організмі щурів, уражених 1,2-диметилгідразином.

Матеріал і методи дослідження. Експерименти проведені на 70 білих щурах-самцях, яких утримували на стандартному раціоні віварію Тернопільського національного медичного університету імені І. Я. Горбачевського. Маса тіла тварин становила 180-220 г. Усі маніпуляції з експериментальними тваринами проводили з дотриманням правил «Європейської конвенції про захист хребетних тварин, що використовуються для дослідних та інших наукових цілей», а також згідно «Науково-практичних рекомендацій з утримання лабораторних тварин та роботи з ними» [13].

Щурів було поділено на 3 групи: 1 - контрольна (інтактні тварини); 2 - тварини, уражені ДМГ; 3 тварини, уражені ДМГ, яким після 30 тижня застосування канцерогену вводили ентеросорбент АУТ.

Канцерогенез моделювали шляхом введення несиметричного 1,2-диметилгідразин гідрохлориду (фірми «SIGMA-ALDRICH CHEMIE», виробництва Японії), попередньо розведеного ізотонічним розчином натрію хлориду. ДМГ вводили 
Огляди літератури, оригінальні дослідження, погляд на проблему, випадок з практики, короткі повідомлення підшкірно в міжлопаткову ділянку в дозі 7,2 мг/кг (з розрахунку на діючу речовину) 1 раз на тиждень упродовж 30 тижнів відповідно до маси тварини з розрахунку 0,1 мл розчину ДМГ на 100 г маси тіла щура. Сорбційний препарат АУТ вводили інтрагастрально щоденно впродовж 21 доби після моделювання канцерогенезу. Добова доза сорбенту - 1 мл завису (що відповідає 0,2 г чистої маси препарату) на 100 г маси тіла тварини.

Кожного місяця від початку дослідження уражених тварин виводили з експерименту шляхом евтаназії під тіопенталовим наркозом. Для дослідження брали сироватку крові тварин та гомогенат печінки. Активність процесів ліпопероксидації оцінювали за вмістом ТБК-активних продуктів (ТБК-АП) у сироватці крові та печінці щурів [4]. Інтенсивність процесів окисної модифікації протеїнів (ОМП) визначали за методикою R. Levine шляхом реєстрації оптичної щільності аліфатичних альдегідо- та кетодинітрофенілгідразонів основного і нейтрального характеру - 2,4-динітрофенілгідразонів (2,4-ДНФГ) [1]. Досліджували активність антиоксидантних ензимів супероксиддисмутази (СОД) [10] та каталази [3].

Отримані експериментальні дані статистично обробляли методом варіаційної статистики за допомогою стандартного пакету статистичної про-

грами «Statistica 6.0». Визначали середньоквадратичні відхилення, дисперсію та інші статистичні параметри, а розрахунки похибок вимірювання встановлювали з використанням Е-критерію Стьюдента. Зміни вважали вірогідними при p $\leq 0,05$ [16].

Результати й обговорення. В умовах індукованого канцерогенезу відбувається надмірне утворення та накопичення активних форм оксигену (АФО), що призводить до розвитку оксидативного стресу та $\epsilon$ пусковим механізмом до деструкції інших молекул (ліпідів). Оксидативний стрес викликає порушення показників антиоксидантного захисту організму $[2,5]$.

Відомо, що маркером раннього розвитку оксидативного стресу є окисна модифікація протеїнів (ОМП), що супроводжується їх денатурацією, утворенням амінокислотних радикалів, які далі вступають у вторинну взаємодію з сусідніми амінокислотними залишками [6]. Усі ці процеси призводять до втрати протеїнами їхньої біологічної активності й порушення обміну речовин. Крім того, негативний ефект ОМП пов'язують із тим, що вони є джерелом вільних радикалів і виснажують запаси клітинних антиоксидантів [7].

Ступінь ОМП оцінювали за рівнем кето- та альдегідопохідних нейтрального $\left(\mathrm{OMП}_{370}\right)$ та основного $\left(О \mathrm{MП}_{430}\right)$ характеру (табл. 1).

Таблиця 1. Вміст продуктів окисної модифікації протеїнів у сироватці крові та печінці щурів (мкмоль/г протеїну) у динаміці ураження 1,2-ДМГ та після застосування сорбенту АУТ

\begin{tabular}{|l|c|c|c|c|}
\hline \multirow{2}{*}{ Група тварин/ термін ураження } & \multicolumn{2}{|c|}{ ОМП $_{370}$} & \multicolumn{2}{c|}{ ОМП $_{430}$} \\
\cline { 2 - 4 } & сироватка & печінка & сироватка & печінка \\
\hline Інтактний контроль & $0,15 \pm 0,01$ & $0,29 \pm 0,02$ & $0,30 \pm 0,02$ & $0,38 \pm 0,02$ \\
\hline 1 місяць & $0,34 \pm 0,02 *$ & $0,41 \pm 0,02 *$ & $0,39 \pm 0,02 *$ & $0,56 \pm 0,04^{*}$ \\
\hline 2 місяць & $0,47 \pm 0,03^{*}$ & $0,47 \pm 0,03^{*}$ & $0,49 \pm 0,02^{*}$ & $0,64 \pm 0,04^{*}$ \\
\hline 3 місяць & $0,51 \pm 0,04^{*}$ & $0,60 \pm 0,04^{*}$ & $0,57 \pm 0,04^{*}$ & $0,68 \pm 0,04^{*}$ \\
\hline 4 місяць & $0,59 \pm 0,04^{*}$ & $0,68 \pm 0,04^{*}$ & $0,64 \pm 0,05^{*}$ & $0,73 \pm 0,05^{*}$ \\
\hline 5 місяць & $0,68 \pm 0,05^{*}$ & $0,70 \pm 0,05^{*}$ & $0,74 \pm 0,05^{*}$ & $0,80 \pm 0,06^{*}$ \\
\hline 6 місяць & $0,74 \pm 0,05^{*}$ & $0,72 \pm 0,06^{*}$ & $0,80 \pm 0,05^{*}$ & $0,83 \pm 0,06^{*}$ \\
\hline 7 місяць & $0,81 \pm 0,06^{*}$ & $0,78 \pm 0,06^{*}$ & $0,86 \pm 0,06^{*}$ & $0,91 \pm 0,08^{*}$ \\
\hline ДМГ+АУТ(14 днів) & $0,59 \pm 0,04^{* *}$ & $0,62 \pm 0,05$ & $0,71 \pm 0,06$ & $0,77 \pm 0,05$ \\
\hline ДМГ+АУТ(21 день) & $0,51 \pm 0,03^{* *}$ & $0,54 \pm 0,03 * *$ & $0,56 \pm 0,05^{* *}$ & $0,70 \pm 0,04^{* *}$ \\
\hline
\end{tabular}

Примітка. Тут і в наступних таблицях: * - вірогідні зміни між показниками тварин інтактного контролю та щурів, уражених 1,2-диметилгідразин гідрохлоридом (p $\leq 0,05)$; ** - вірогідні відмінності між показниками уражених 1,2-диметилгідразин гідрохлоридом щурів та щурів, яким вводили сорбент АУТ $(p \leq 0,05)$.

У сироватці крові та печінці уражених тварин показник ОМП 370 підвищився на 1-й місяць моделювання канцерогенезу в 2,3 та 1,4 раза відповідно, порівняно із тваринами контрольної групи (інтактний контроль), на 7-й місяць дослідження цей показник збільшився, порівняно із неураженими тваринами, у сироватці - в 5,4 раза, у печінці - в
2,7 раза. Схожу динаміку підвищення показників альдегідо- та кетопохідних основного характеру $\left(O M \Pi_{430}\right)$ виявлено в сироватці крові уражених щурів та їх печінці протягом всього екперименту: на 1-й місяць у сироватці крові показник підвищився в 1,3 раза, в печінці - в 1,4 раза, порівняно із відповідними показниками тварин групи інтакт- 
Огляди літератури, оригінальні дослідження, погляд на проблему, випадок з практики, короткі повідомлення ного контролю. На 7-й місяць експерименту вміст $\mathrm{OM}_{430}$ у сироватці крові підвищився у 2,9 раза, у печінці - в 2,4 раза щодо норми.

Для зменшення негативного впливу оксидативного стресу на організм ми використали ентеросорбент АУТ. Використаний нами вуглецевий сорбент призводить до вірогідного зниження $(p \leq 0,05)$ вмісту OMП 370 та ОМП 430 у сироватці крові та печінці уражених 1,2-ДМГ тварин. Вміст ОМП 370 на 21 добу застосування у сироватці та печінці щурів знизився на $37 \%$ та $31 \%$ відповідно, ОМП $430-$ на $35 \%$ та $23 \%$, прівняно з показниками уражених тварин.

Отримані результати підтверджують позитивний вплив ентеросорбенту АУТ на показники ОМП, знижуючи їх у досліджуваних тканинах, що приводило до зменшення проявів оксидативного стресу.

Введений в організм щурів ДМГ викликає активацію процесів ліпопероксидації, що може призвести до порушення в структурі мембран клітин $[9,18]$. У тварин із змодельованим канцерогенезом було виявлено статистично вірогідне збільшення вмісту ТБК-АП вже в 1-й місяць ураження, у сироватці крові цей показник підвищився в 2,4 раза, у печінці - в 2,9 раза, порівняно з інтактним контролем (табл. 2).

Таблиця 2. Вміст ТБК-активних продуктів у сироватці крові та печінці щурів у динаміці ураження 1,2-ДМГ та при застосуванні сорбенту АУТ

\begin{tabular}{|l|c|c|}
\hline \multicolumn{1}{|c|}{ Група тварин/ термін ураження } & Сироватка крові, мкмоль/л & Печінка, мкмоль/л \\
\hline контроль & $1,93 \pm 0,09$ & $16,27 \pm 0,93$ \\
\hline 1 місяць & $4,72 \pm 0,30^{*}$ & $47,26 \pm 2,75^{*}$ \\
\hline 2 місяць & $8,31 \pm 0,51^{*}$ & $50,42 \pm 3,83^{*}$ \\
\hline 3 місяць & $9,69 \pm 0,57^{*}$ & $56,71 \pm 4,10^{*}$ \\
\hline 4 місяць & $11,12 \pm 0,65^{*}$ & $60,50 \pm 4,87^{*}$ \\
\hline 5 місяць & $11,93 \pm 0,69^{*}$ & $68,67 \pm 5,23^{*}$ \\
\hline 6 місяць & $12,90 \pm 0,76^{*}$ & $73,96 \pm 5,34^{*}$ \\
\hline 7 місяць & $13,70 \pm 0,77^{*}$ & $74,02 \pm 5,45^{*}$ \\
\hline ДМГ+АУТ(14 днів) & $10,80 \pm 0,60^{* *}$ & $55,29 \pm 3,62^{* *}$ \\
\hline ДМГ+АУТ(21 день) & $9,05 \pm 0,56^{* *}$ & $50,52 \pm 3,20^{* *}$ \\
\hline
\end{tabular}

На 7-й місяць досліження даний показник підвищився, порівняно з контрольною групою, у сироватці крові - в 7 разів, у печінці-в 4,5 раза. На тлі використання сорбенту АУТ (21 доба) Вміст ТБК-АП у сироватці крові був нижчим на 34 \%, в печінці на 32 \%, відносно рівня уражених тварин.

В умовах експериментального канцерогенезу товстої кишки у щурів підвищення вмісту ТБК АП свідчить про посилення процесів пероксидного окиснення ліпідів i, як наслідок, зниження активності ензимів антиоксидантної системи захисту - СОД та каталази.

Відомо, що супероксиддисмутаза є представником першої лінії антиоксидантного захисту та забезпечує переривання ланцюгів кисневозалежних вільнорадикальних реакцій шляхом дисмутації супероксидного аніон-радикала (О²) з подальшим утворенням триплетного оксигену та пероксиду гідрогену $[9,11]$.

Ми встановили статистично вірогідне зниження СОД активності за умов індукованого канцерогенезу, починаючи з 4-го місяця ураження (на 23 \%) (рис. 1).

Цей показник має тенденцію до зниження і в наступні місяці експерименту (7-й місяць - на
42 \%). Зниження СОД активності у сироватці крові може свідчити про збільшення в клітині концентрації гідроген пероксиду та інактивацію каталази, яка його розщеплює до води та кисню [10].

Пригнічення СОД активності може бути обумовлено суттєвим виснаженням пулу ензимів внаслідок посиленого їх використання на нейтралізацію вільних радикалів, продукція яких значно інтенсифікується в організмі тварин за умов експериментального канцерогенезу.

3 іншого боку, достовірно відомо про безпосередній вплив активних форм оксигену на ступінь окиснення іонів металів в активних центрах ензимів, що обумовлює пригнічення їх функціонування [19]. Ще однією з причин зниження супероксиддисмутазної активності може бути накопичення пероксиду гідрогену, який $є$ інгібітором супероксиддисмутази [20].

Доцільним було дослідити каталазну активність у сироватці крові та печінці щурів, уражених ДМГ та вплив на неї ентеросорбенту АУТ. Каталазна активність у сироватці крові уражених щурів вірогідно $(p \leq 0,05)$ знизилась на 3-й місяць експерименту (на 38 \%) та продовжувала знижуватися впродовж наступних місяців ураження (7-й місяць на $69 \%$ ) (рис. 2). 
Огляди літератури, оригінальні дослідження, погляд на проблему, випадок з практики, короткі повідомлення

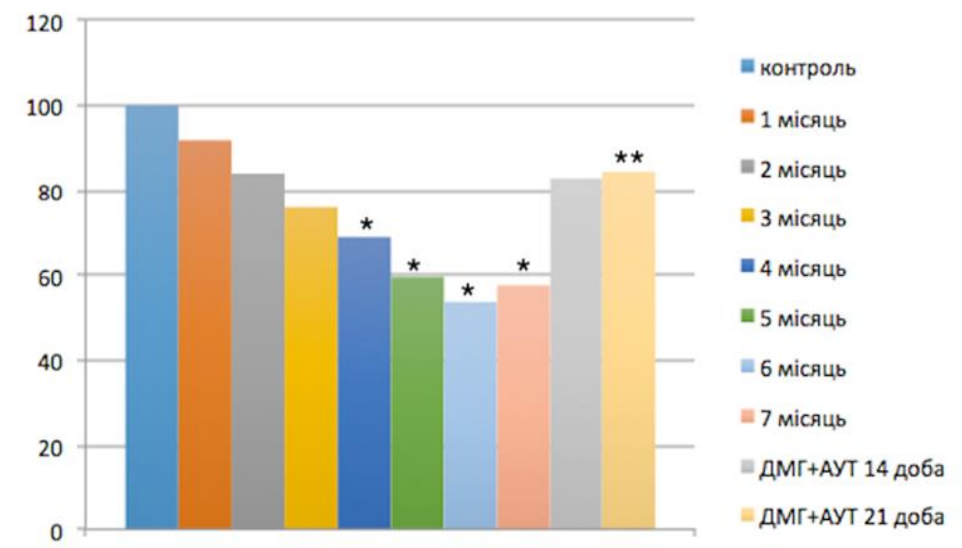

Примітка. Тут і на наступних рисунках: * - вірогідні зміни між показниками тварин інтактного контролю та щурів, уражених 1,2-диметилгідразин гідрохлоридом ( $\leq 0,05)$;* - вірогідні відмінності між показниками уражених 1,2-диметилгідразин гідрохлоридом щурів та щурів, яким вводили сорбент АУТ ( $\leq \leq 0,05)$.

Рис. 1. Динаміка супероксидисмутазної активності у сироватці крові щурів при ураженні 1,2-диметилгідразин гідрохлоридом і застосуванні сорбенту АУТ, \%.

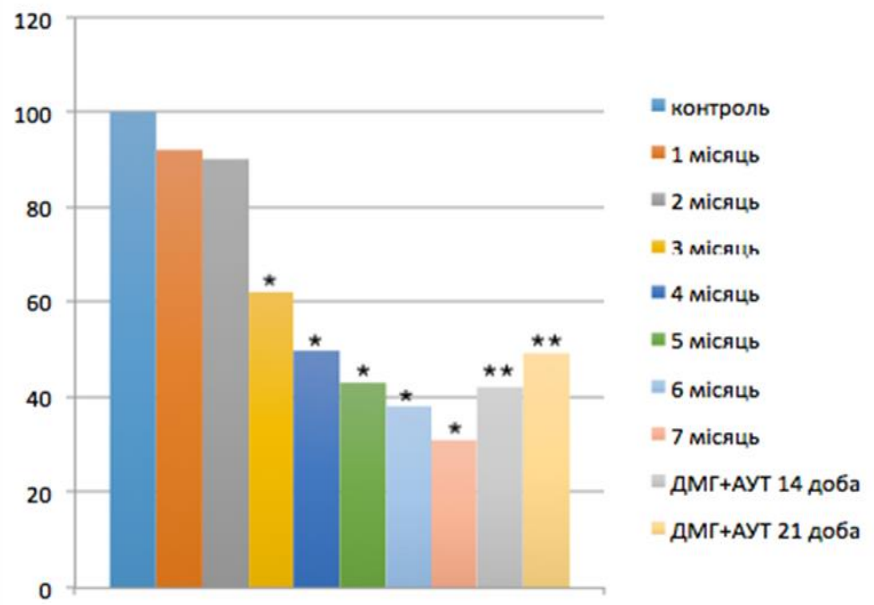

Рис. 2. Динаміка каталазної активності у сироватці крові щурів при ураженні 1,2-диметилгідразин гідрохлоридом і застосуванні сорбенту АУТ, \%.

В умовах індукованого канцерогенезу товстої кишки ми виявили зниження активності даного показника у печінці (рис. 3). Активність ензиму вірогідно ( $\leq 0,05)$ знижувалася з 2-го місяця ураження на $27 \%$, на 7-й місяць експерименту на $72 \%$.

Однією із причин зниження активності ензиму може бути викликана тривалою дією токсину (30 тижнів) деградація вільних та зв'язаних із мембранами ендоплазматичної сітки рибосом, які відповідають за синтез протеїнів.

Застосування ентеросорбенту АУТ позитивно вплинуло на показники ензиматичної ланки антиоксидантної системи. Після його введення в уражений організм СОД активність на 21-шу добу використання сорбенту збільшилася на 50 \%. Також зафіксовано підвищення каталазної активності у печінці та сироватці крові досліджуваних тварин у цей же термін під впливом сорбента (на 85 \% та 57 \% відповідно).

Результати наших досліджень свідчать, що АУТ сприяє зниженню вмісту продуктів ліпопероксидації та окисної модифікації протеїнів, а також приводить до відновлення активності антиоксидантних ензимів у щурів при раку товстої кишки.

Отже, в умовах ДМГ-індукованого канцерогенезу порушується рівновага між інтенсивністю дії прооксидантних факторів і потужністю антиоксидантної системи щурів, що призводить до надмірної активації процесів пероксидного окиснення ліпідів та окисної модифікації протеїнів [15]. Застосування ентеросорбенту АУТ приводить до відновлення показників антиоксидантної систе- 
Огляди літератури, оригінальні дослідження, погляд на проблему, випадок з практики, короткі повідомлення

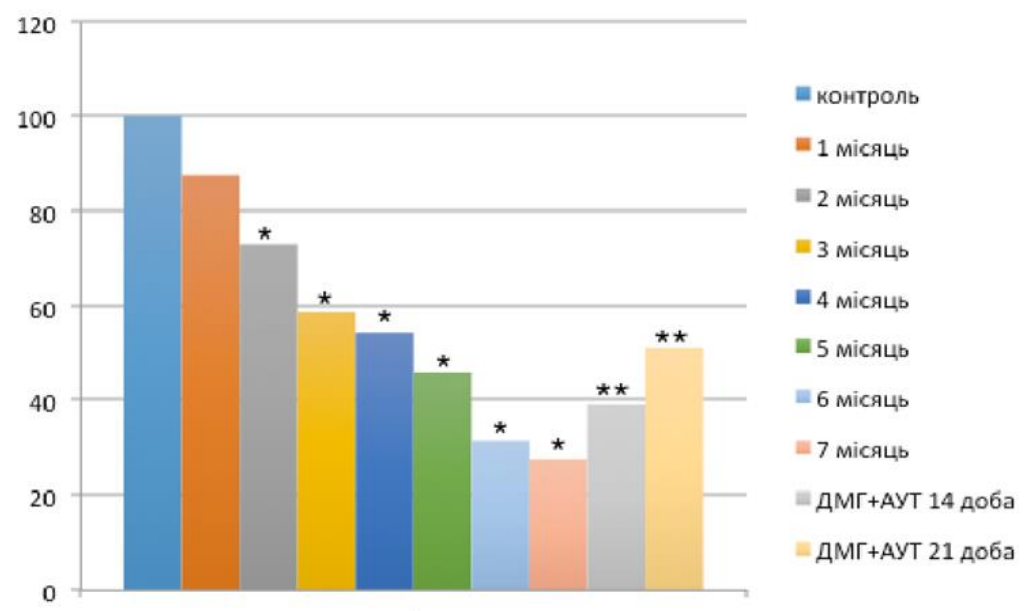

Рис. 3. Динаміка каталазної активності у печінці щурів при ураженні 1,2-диметилгідразин гідрохлоридом і застосуванні сорбенту АУТ, \%.

ми організму уражених щурів, що вказує на перспективність його подальшого вивчення.

Висновки. 1. Вумовах індукованого канцерогенезу розвивається оксидативний стрес, про що свідчить достовірне підвищення протягом експерименту продуктів ліпопероксидації та окиснювальної модифікації протеїнів. На це вказує підвищений вміст ТБК-активних продуктів та 2,4-динітрофенілгідразонів у сироватці крові та печінці уражених щурів.

2. На тлі розвитку оксидативного стресу в уражених ДМГ щурів відмічено пригнічення активності антиоксидантних ензимів (супероксиддисмутази та каталази), показники яких прогресивно знижувалися до кінця експерименту, як у сироватці крові, так і в печінці тварин.

\section{ЛІТЕРАТУРА}

1. Дубініна $€$. $Є$. Окиснювальна модифікація протеїнів, їх роль при патологічних станах / Є. Є. Дубініна, А. В. Пустигіна // Український біохімічний журнал. 2008. - T. 80, № 6. - С. 5-18.

2. Зинь А. Прооксидантно-антиоксидантний гомеостаз і мембранний транспорт у живих організмах / А. Зинь // Вісник Львівського університету. -2012. - Випуск 60. - С. 21-39.

3. Королюк М. А. Метод определения активности каталазы / М. А. Королюк, Л. И. Иванова, И. Г. Майорова // Лаб. дело. - 1988. - № 1. - С. 16-19.

4. Лущак В. І. Показники оксидативного стресу. Тіобарбітурактивні продукти і карбонільні групи білків / В. І. Лущак, Т. В. Багнюкова, О. В. Лущак // Укр. біохім. журн. - 2004. - Т. 76, № 6. - С. 136-141.

5. Марущак М. І. Роль активних форм кисню у розвитку та прогресуванні гострого ураження легень в експерименті / М. І. Марущак // Мед. хімія. - 2012. № 1 (50). - C. 104-108.
3. Ентеросорбент АУТ, який уражені ДМГ щури отримували протягом 21 дня, привів до зниження активності вільнорадикальних процесів, що супроводжувалося відновленням показників ензиматичної ланки антиоксидантного захисту, зокрема, супероксиддисмутазної та каталазної активності, як на 14, так і на 21 добу після його застосування.

Перспективи подальших досліджень. Подальше поглиблене вивчення можливості застосування ентеросорбенту АУТ в умовах експериментального канцерогенезу дозволить запропонувати його використання у загальних схемах лікування онкохворих з метою зниження проявів ендогенної інтоксикації.

6. Пероксидне окиснення білків стінки тонкої кишки, міокарда та печінки щурів при експериментальному застосуванні карагінану / М. І. Марущак, О. М. Копаниця, І. Я. Криницька, Т. Я. Ярошенко // Медична та клінічна хімія. - 2017. - Т. 19, № 4. - С. 109-114.

7. Муравьева Л. Е. Окислительная модификация белков: проблемы и перспективы исследования / Л. Е. Муравьева // Фундаментальные исследования. 2010. - № 1. - С. 74-78.

8. Сорока Ю. Сорбційна корекція змін імунологічної реактивності щурів за умов експериментального канцерогенезу та застосування хіміотерапевтичних чинників / Ю. Сорока // Світ медицини та біології. 2013. - № 4 (41). - С. 82-86.

9. Стан антиоксидантної системи печінки та вміст матриксної металопротеїнази-2-товстого кишечника у разі дії похідного малеіміду за експериментального колоректального канцерогенезу щурів / О. М. Філіпінська, С. В. Яблонська, С. Я. Мандрик [та ін.] // 
Огляди літератури, оригінальні дослідження, погляд на проблему, випадок з практики, короткі повідомлення

Український біохімічний журнал. - 2010. - № 4. C. 69-77.

10. Чевари С. Роль супероксиддисмутазы в окислительных процессах клетки и метод определения ее в биологических материалах / С. Чевари, И. Чаба, И. Секей // Лаб. дело. - 1985. - № 11. - С. 678-681.

11. Oxidative stress and severity of coronary artery disease in young smokers with acute myocardial infarction / S. Aksoy, N.Cam, U. Gurcan [et al.] // Cardiology Journal. - 2012. - No. 19 (4). - P. 381-386. DOI: 10.5603/ CJ.2012.0069. [PubMed]

12. Arigesavan K. Carvacrol exhibits anti-oxidant and anti-inflammatory effects against 1, 2-dimethyl hydrazine plus dextran sodium sulfate induced inflammation associated carcinogenicity in the colon of Fischer 344 rats / K. Arigesavan, G. Sudhandiran // Biochem. Biophys. Res. Commun. - 2015. - No. 461 (2). - P. 314-320.

13. Gross D. Ethics in Animal-Based Research / D. Gross, R. Tolba // Eur. Surg. Res. - 2015. - Vol. 55, Issue 1-2. P. 43-57. DOI: 10.1159/000377721.

14. Amelioration of 1,2 Dimethylhydrazine (DMH) Induced Colon Oxidative Stress, Inflammation and Tumor Promotion Response by Tannic Acid in Wistar Rats / O. O. Hamiza, M. U. Rehman, M. Tahir [et al.] // Asian Pacific Journal of Cancer Prevention. - 2012. - No. 13 (9). - P. 4393-402.

\section{REFERENCES}

1. Dubinina, Ye.Ye., \& Pustyhina, A.V. (2008). Okysniuvalna modyfikatsiia proteiniv, yikh rol pry patolohichnykh stanakh [Oxidative modification of proteins, their role in pathological conditions]. Ukrainskyi biokhimichnyi zhurnal - Ukrainian Biochemical Journal, 80 (6), 5-18 [in Ukrainian].

2. Zyn, A. (2012). Prooksydantno-antyoksydantnyi homeostaz i membrannyi transport u zhyvykh orhanizmakh [Prooxidant-antioxidant homeostasis and membrane transport in living organisms]. Visnyk Lvivskoho universytetu - Visnyk of Lviv National University, 60, 21-39 [in Ukrainian].

3. Koroliuk, M.A., Ivanova, L.I. \& Maiorova, I.H. (1988). Metod opredeleniya aktivnosti katalazy [Method for determining the activity of catalase]. Lab. Delo- Lab. Business, 1, 16-19 [in Russian].

4. Lushchak, V.I., Bahniukova, T.V. \& Lushchak, O.V. (2004). Pokaznyky oksydatyvnoho stresu. Tiobarbituraktyvni produkty i karbonilni hrupy bilkiv [Indicators of oxidative stress. Thiobarbiturative products and carbonyl groups of proteins]. Ukrainskyi biokhimichnyi zhurnal Ukrainian Biochemical Journal, 76 (6), 136-141 [in Ukrainian].

5. Marushchak, M.I. (2012). Rol aktyvnykh form kysniu u rozvytku i prohresuvanni hostroho urazhennia lehen v eksperymenti [Role of reactive oxygen species in the development and progression of acute lung injury in experiment]. Med. khimiia - Med. Chemistry, 1 (50), 104-108 [in Ukrainian].

6. Marushchak, M.I., Kopanytsia, O.M., \& Krynytska, I.A., Yaroshenko, T.Ya. (2017). Peroksydne okysnennia
15. Thymoquinone, the Nigella sativa bioactive compound, prevents circulatory oxidative stress caused by 1,2-dimethylhydrazine in erythrocyte during colon postinitiation carcinogenesi / H. J. Harzallah, R. Grayaa, W. Kharoubi [et al.] // Oxid. Med. Cell. Longev. - 2012. - No. 12. P. 1-6.

16. Okeh U. Statistical problems in medical research / U. Okeh // East. Afr. J. Public. Health. - 2009. - Vol. 6, Issue 1. - P. 1-7.

17. Perše M. The dimethylhydrazine induced colorectal tumours in rat - experimental colorectal carcinogenesis / M. Perše, A. Cerar // Radiology and Oncology. - 2005. No. 21 (3). - P. 61-70.

18. Perše M. Morphological and molecular alterations in 1,2 dimethylhydrazine and azoxymethane induced colon carcinogenesis in rats / M. Perše, A. Cerar // Journal of Biomedicine and Biotechnology. - 2010. - No. 3. - P. 1-14.

19. Ray P. D. Reactive oxygen species (ROS) homeostasis and redox regulation in cellular signaling / P. D. Ray, B. W. Huang, Y. Tsuji // Cellular Signalling. - 2012. - No. 24 (5). P. 981-990. DOI: 10.1016/j.cellsig.2012.01.008.

20. Schieber M. ROS function in redox signaling and oxidative stress / M. Scieber, N. S. Chandel // Curr. Biol. 2014. - No. 24 (10). - P. 453-462. DOI: 10.1016/j.cub.2014. 03.034. [PubMed]. bilkiv stinky tonkoi kyshky, miokarda ta pechinky shchuriv pry eksperymentalnomu zastosuvanni karahinanu [Peroxidation of proteins of the small intestine wall, myocardium and rat liver in experimental use of carrageenan]. Medychna ta klinichna khimiia - Medical and Clinical Chemistry, 4, 109-114 [in Ukrainian].

7. Muraveva, L. (2010). Okyslytelnaya modyfikatsiya belkov: problemy i perspektyvy issledovaniya [Oxidative modification of proteins: problems and prospects of research]. Fundamentalnye issledovaniya - Fundamental Researches, 1, 74-78 [in Russian].

8. Soroka, Yu. (2013). Sorbtsiina korektsiia zmin imunolohichnoi reaktyvnosti shchuriv za umov eksperymentalnoho kantserohenezu ta zastosuvannia khimioterapevtychnykh chynnykiv [Sorption correction of changes in the immunological reactivity of rats under experimental carcinogenesis and the use of chemotherapeutic factors]. Svit medytsyny ta biolohii - World of Medicine and Biology, 4 (41), 82-86 [in Ukrainian].

9. Filipinska, O.M. (2010). Stan antyoksydantnoi systemy pechinky ta vmist matryksnoi metaloproteinazy-2tovstoho kyshechnyka u razi dii pokhidnoho maleimidu za eksperymentalnoho kolorektalnoho kantserohenezu shchuriv [The state of the antioxidant system of the liver and the content of matrix metalloproteinase-2-large intestine in the case of action of a derivative of maleimide in experimental colorectal carcinogenesis of rats]. Ukrainskyi biokhimichnyi zhurnal - Ukrainian Biochemical Journal, 4, 6977 [in Ukrainian]. 
Огляди літератури, оригінальні дослідження, погляд на проблему, випадок з практики, короткі повідомлення

10. Chevari, S., Chaba, I. \& Sekey, I. (1985). Rol superoksiddismutazy v okislitelnykh protsessakh kletki i metod opredeleniya yeye $v$ biologicheskikh materialakh [The role of superoxide dismutase in the oxidative processes of the cell and the method for determining it in biological materials]. Lab. delo - Lab. Business, 1, 678-681 [in Russian].

11. Aksoy, S., Cam, N., Gurcan, U., Oz, D., Ozden, K. Altay, S., Durmus G., \& Agirbasli M. (2012). Oxidative stress and severity of coronary artery disease in young smokers with acute myocardial infarction. Cardiology Journal, 19 (4), 381-6. doi: 10.5603/CJ.2012.0069. [PubMed].

12. Arigesavan, K., \& Sudhandiran, G. (2015). Carvacrol exhibits anti-oxidant and anti-inflammatory effects against 1, 2-dimethyl hydrazine plus dextran sodium sulfate induced inflammation associated carcinogenicity in the colon of Fischer 344 rats. Biochem. Biophys. Res. Commun., 461 (2), 314-320.

13. Gross, D., \& Tolba, R. (2015). Ethics in animal-based research. Eur. Surg. Res., 1-2, 43-57. doi: $10.1159 / 000377721$.

14. Hamiza, O.O., Rehman, M.U., Tahir, M., Khan, R., Khan, A.Q., Lateef, A., Ali, F., et al. (2012). Amelioration of 1,2 dmethylhydrazine (DMH) induced colon oxidative stress, inflammation and tumor promotion response by tannic acid in wistar rats. Asian Pacific Journal of Cancer Prevention, 13 (9), 4393-4402.

15. Harzallah, H.J., Grayaa, R., Kharoubi, W., Maaloul, A., Hammami, M., \& Mahjoub, T. (2012). Thymoquinone, the $\mathrm{Ni}$ gella sativa bioactive compound, prevents circulatory oxidative stress caused by 1,2-dimethylhydrazine in erythrocyte during colon postinitiation carcinogenesi. Oxid. Med. Cell Longev., 4, 1-6.

16. Okeh, U. (2009). Statistical problems in medical research. East. Afr. J. Public. Health., 6 (1), 1-7.

17. Perše, M., \& Cerar, A. (2005). The dimethylhydrazine induced colorectal tumours in rat - experimental colorectal carcinogenesis. Radiology and Oncology, 39 (1), 61-70.

18. Perše, M., \& Cerar, A. (2010). Morphological and molecular alterations in 1,2 dimethylhydrazine and azoxymethane induced colon carcinogenesis in rats. Journal of Biomedicine and Biotechnology, 21, 1-14.

19. Ray, P.D., Huang, B.W., \& Tsuji, Y. (2012). Reactive oxygen species (ROS) homeostasis and redox regulation in cellular signaling. Cellular Signalling, 24 (5), 981-990. doi: 10.1016/j.cellsig.2012.01.008.

20. Schieber, M., \& Chandel, N.S. (2014). ROS function in redox signaling and oxidative stress. Curr. Biol., 24 (10), 453-462. doi:10.1016/j.cub.2014. 03.034. [PubMed].

\title{
ПРИМЕНЕНИЕ ЭНТЕРОСОРБЕНТА АУТ ДЛЯ КОРРЕКЦИИ ОКИСЛИТЕЛЬНЫХ ПРОЦЕССОВ ПРИ ЭКСПЕРИМЕНТАЛЬНОМ КОЛОРЕКТАЛЬНОМ КАНЦЕРОГЕНЕЗЕ У КРЫС
}

\author{
Тернопольский национальный медицинский университет имени И. Я. Горбачевского Мз Украины
}

РЕЗЮМЕ. Злокачественные новообразования толстой кишки являются одними из наиболее распространенных заболеваний желудочно-кишечного тракта. Для лечения данных заболеваний, кроме противоопухолевой терапии, применяют терапию сопровождения, в частности энтеросорбцию, которая предназначена для выведения токсических веществ из организма.

Цель - оценить эффективность использования энтеросорбента АУТ и его влияние на показатели оксидативного стресса в организме крыс в условиях экспериментального канцерогенеза.

Материал и методы. Эксперименты выполнены на белых крысах-самцах, которым моделировали рак толстой кишки путем еженедельного подкожного введения 1,2-диметилгидразина в дозе 7,2 мг/кг массы тела в течение 30 недель. Энтеросорбент АУТ вводили интрагастрально ежедневно в течение 21 суток после моделирования канцерогенеза в дозе 1 мл взвеси (что соответствует 0,2 г чистой массы продукта) на 100 г массы тела животного. Развитие оксидативного стресса изучали по активности окислительной модификации протеинов, концентрации продуктов перекисного окисления липидов, супероксиддисмутазной и каталазной активности.

Результаты. Установлено, что после поражения 1,2-диметилгидразин гидрохлоридом развивается оксидативный стресс, который подтверждается повышением в сыворотке крови и печени крыс содержания ТБК-активных продуктов и 2,4-динитрофенилгидразонов. У экспериментальных животных нарушается проксидантноантиоксидантный баланс, на что указывает снижение активности показателей энзиматического звена антиоксидантной системы. Применение энтеросорбента АУТ способствовало нормализации окислительных процессов и восстановлению активности энзиматического звена антиоксидантной системы в условиях индуцированного канцерогенеза.

Вывод. Полученные результаты подтверждают положительную динамику использования детоксикационной терапии сорбентом АУТ во время прогрессирующего развития оксидативного стресса в условиях смоделированного канцерогенеза.

КЛЮЧЕВЫЕ СЛОВА: оксидативный стресс; антиоксидантная система; диметилгидразин; энтеросорбент АУТ; окислительная модификация протеинов. 
Огляди літератури, оригінальні дослідження, погляд на проблему, випадок з практики, короткі повідомлення

THE APPLICATION OF THE ENTEROSORBENT AUT FOR THE CORRECTION OF OXIDATION PROCESSES FOR EXPERIMENTAL COLORECTAL CARCENOGENESIS IN RATS

๑O. I. Kachur, L. S. Fira, P. H. Lykhatskyi

\section{Horbachevky Ternopil National Medical University}

SUMMARY. Malignant neoplasms of the colon are one of the most common diseases of the gastrointestinal tract. The process of tumor development is accompanied by hyperfunction of reactive oxygen species with subsequent violation of the body's antioxidant protection. Therefore, in addition to antitumor therapy, the use of accompaniment therapy, in particular, enterosorption.

The aim of the study - to evaluate the efficacy of using enterosorbent AUT and its effect on oxidative stress in rats affected by 1,2-dimethylhydrazine.

Material and Methods. The experiments were performed on white male rats, who modeled colon cancer by weekly subcutaneous administration of 1,2-dimethylhydrazine at a dose of $7.2 \mathrm{mg} / \mathrm{kg}$ body weight for 30 weeks. Enterosorbent AUT was administered intragastrically daily for 21 days after modeling of carcinogenesis at a dose of $1 \mathrm{ml}$ of suspension (corresponding to $0.2 \mathrm{~g}$ net weight of the preparation) per $100 \mathrm{~g}$ of body weight of the animal. The development of oxidative stress was studied by the activity of protein oxidative modification, the concentration of products of lipid peroxidation (LPO) by the activity of superoxide dismutase (SOD), catalase.

Results. It was established that oxidative stress develops during carcinogen administration of 1,2-dimethylhydrazine hydrochloride. In experimental animals, the peroxidant and antioxidant balance is disturbed, accompanied by a decrease in the antioxidant system. The use of enterosorbent AUT contributed to the normalization of these indicators.

Conclusions. The results confirm the positive dynamics of the use of detoxification therapy with sorbent AUT during the progressive development of oxidative stress under the conditions of simulated carcinogenesis.

KEY WORDS: oxidative stress; antioxidant system; dimethylhydrazine; enterosorbent AUT; oxidative modification of the protein.

Отримано 22.08.2019 